\title{
Severe ovarian hyperstimulation syndrome in spontaneous pregnancy treated successfully with cabergoline
}

\author{
İsmail Temur, ${ }^{1}$ Murat Bozkurt, ${ }^{1}$ Servet Gencdal, ${ }^{1}$ Yetkin Karasu, ${ }^{1}$ Duygu Kara Bozkurt, ${ }^{2}$ \\ Hacer Pasaoğlu, ${ }^{1}$ Kahraman Ülker, $^{1}$ Suat Dede ${ }^{1}$
}

Keywords: Ovarian hyperstimulation syndrome (OHSS), spontaneous pregnancy, ascites, pleural effusion, cabergoline

\begin{abstract}
Ovarian hyperstimulation syndrome (OHSS) is a relatively common complication in infertile patients treated with exogenous gonadotropins. Ovarian hyperstimulation in spontaneous pregnancies is a rare but possible. The pathogenesis of spontaneous OHSS is not well known. Risk factors for OHSS are young age, polycystic ovaries, low body mass index, high gonadotropin dose, increased estradiol and human chorionic gonadotropin levels, multiple pregnancy, OHSS history, molar pregnancy and hypothyroidism. In this report we present a case of severe spontaneous OHSS with a brief summary of the literature. She was hospitalized and treated in the clinic with the diagnosis of severe OHSS accompanying spontaneous pregnancy.
\end{abstract}

${ }^{1}$ Department of Obstetrics and Gynecology, Kafkas University School of Medicine, Kars, Turkey
${ }^{2}$ Department of Radiology, Kafkas University School of Medicine, Kars, Turkey

\section{Introduction}

Ovarian hyperstimulation syndrome is a relatively common iatrogenic complication of ovulation induction and controlled ovarian hyperstimulation induced with exogenous gonadotropins. ${ }^{1}$ The incidence of OHSS is about $1-10 \%$ and severe OHSS is seen in less than $2 \%$ of cases. $^{2}$ Massive ovarian enlargement, multiple cysts, ascites, oliguria, abdominal pain, hemoconcentration, thrombosis, pleural effusion, electrolyte imbalance, renal failure, acute respiratory distress syndrome, hypovolemia and death can accompany severe OHSS. ${ }^{3}$ OHSS following spontaneous ovulation is very rare. In this report, a case of severe

Please cite this paper as: Temur I, Bozkurt M, Gencdal S, Karasu Y, Bozkurt DK, Pasaoğlu H, Ülker K, Dede S. Severe ovarian hyperstimulation syndrome in spontaneous pregnancy. Proceedings in Obstetrics and Gynecology, 2014;4(3):Article 9 [ 6 p.]. Available from: http://ir.uiowa.edu/pog/. Free full text article.

Corresponding author: Murat Bozkurt, Assistant Professor, Kafkas Üniversity Kampüsü Sağlık Araştırma ve Uygulama Hastanesi Kars/TURKEY. Tel: 905322279072, 905056330044. Fax: 04742251430. E-Mail: jindrmb@yahoo.com

Financial Disclosure: The authors report no conflict of interest.

Received: 14 June 2014; received in revised form:25 September 2014; accepted 8 October 2014; POG in Press, 15 October 2014

Copyright: (c) 2014 Temur et al. This is an open-access article distributed under the terms of the Creative Commons Attribution License, which permits unrestricted use, distribution, and reproduction in any medium, provided the original author and source are credited. 
OHSS accompanying spontaneous singleton pregnancy is summarized.

\section{Case Report}

A 27 year-old gravida 3 para 2 woman presented to the clinic with a complaint of abdominal pain, abdominal distension, dyspnea, nausea and vomiting. She previously had two healthy deliveries at term. The medical history was uneventful and no drug use was reported before or during the pregnancy.

Vital signs of the patient were normal. Abdominal distension and bilateral adnexal pain were noted during the physical examination Transabdominal ultrasonography revealed a 10-week, singleton pregnancy. Both of the ovaries were enlarged and multicystic (Left ovary: 118 x $113 \mathrm{~mm}$, right ovary: 127 x 117) and there were ascites in the abdomen.

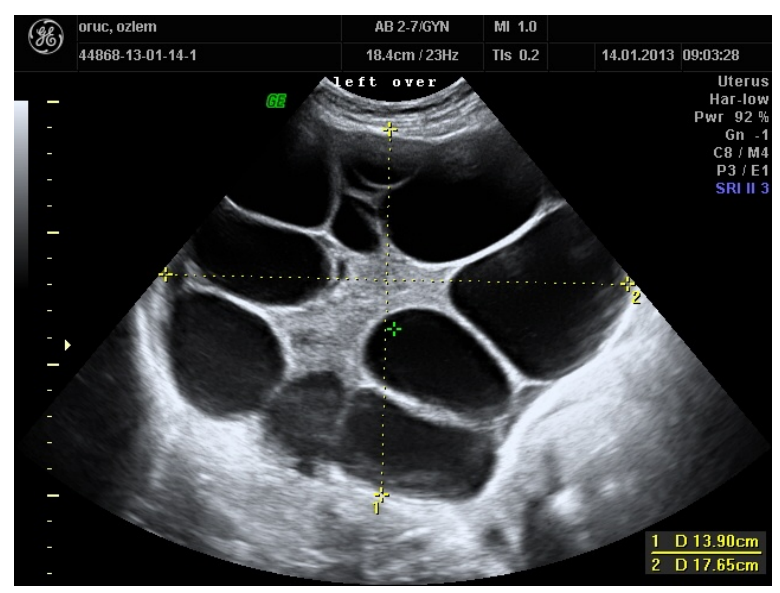

\section{Picture 1. Left Ovary}

Blood tests revealed hemoconcentration (Hb: 16.7 g/dl, Htc: 47.40\%, WBC: 25260, $\quad$ PLT: 360000/mm3), hyponatremia (Na: $123 \mathrm{mmol} / \mathrm{l})$, hypocalcaemia $\quad(7.77 \quad \mathrm{mg} / \mathrm{dl})$, hypoproteinemia (Albumin: $2.2 \mathrm{~g} / \mathrm{l}$ ).

The patient was hospitalized with the diagnosis of severe spontaneous OHSS and treated with intravenous fluid replacement, albumin infusion, and low molecular weight heparin. A specialist performed respiratory physiotherapy. Daily weight and abdominal circumference measurements were performed. Blood tests were also repeated daily and treatment of the patient was managed accordingly.

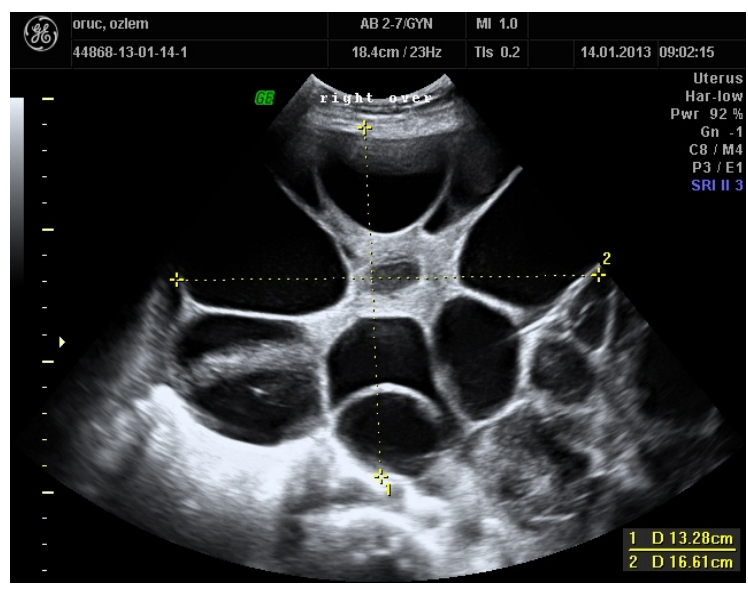

\section{Picture 2. Right Ovary}

After the first week of hospitalization, an increase in body weight and abdominal circumference was seen. The patient had dyspnea, and there was bilateral pleural effusion in the chest x-ray and thoracic ultrasonography. Thoracentesis was performed. The fluid was transude in manner and both cytological and microbiological examinations were normal. There was an increase in the ovarian size (left ovary: 176 × $139 \mathrm{~mm}$, right ovary: $166 \times 132 \mathrm{~mm}$ ) (Picture 1, Picture 2). Cabergoline $0.5 \mathrm{mg} /$ day and dexamethasone $0.5 \mathrm{mg} /$ day treatment was started. 
After four weeks of treatment abdominal distension and dyspnea were dissolved and laboratory tests were normalized. The patient was discharged at 14th weeks of gestation. She was seen at regular visits and delivered uneventfully at the 37th week of pregnancy.

\section{Discussion}

Ovarian hyperstimulation syndrome (OHSS) is an iatrogenic complication of exogenous gonadotropins or sometimes clomiphene citrate used for ovulation induction. ${ }^{4}$ The incidence is about 1$10 \%$ and the severe form constitutes about $1-2 \%$ of the cases. Major risk factors are; young age, PCOS, lean body weight, high dose gonadotropins use, elevated estradiol and human chorionic gonadotropin (hCG) levels, previous OHSS, molar pregnancy, multiple pregnancy and hypothyroidism. ${ }^{6}$ This case had none of these risk factors. Molecular FSH receptor gene defects have been shown in recurrent OHSS cases in some families. ${ }^{7}$ There was not such a finding in our case.

Spontaneous OHSS is a rare entity. De Leener et al. classified spontaneous OHSS into three types: Type I: caused by FSH receptor mutations; Type II: caused by elevated hCG; Type III: hypothyroidism related. ${ }^{8}$ In both type I and type II development of OHSS is hCG mediated. Mutations in FSH receptors may cause increased sensitivity to hCG. Although there is a case of spontaneous OHSS in a nonpregnant adolescent with recurrent OHSS almost all cases in the literature were pregnant. ${ }^{9}$ In this case, since our center does not have the necessary set up, we could not test for FSH receptor mutations.
Vascular endothelial growth factor (VEGF) is blamed as the cause of fluid loss to the third space, hypovolemia, hemoconcentration and electrolyte imbalance. VEGF changes the structure of endothelial gap junctions and increases vascular permeability. ${ }^{10}$ In this case we saw pleural effusion, ascites, hemoconcentration, hypovolemia, and vulvar edema assumed to be related to VEGF. Expression of VEGF mRNA has been shown to be induced by hCG in a dose- and time-dependent fashion. ${ }^{11}$ It was shown that VEGF mRNA expression is increased after luteinizing hormone (LH) surge. ${ }^{12,13}$ Molecular similarity between LH and hCG is important for both progression of the disease and prevention strategies. Dopamine receptor-2 agonist activation decreases ovarian VEGF production and prevents vascular permeability in OHSS rat models. ${ }^{14}$ Polymorphism of VEGF receptor gene itself may also be associated with the occurrence of OHSS. $^{15}$

OHSS can be classified as mild, moderate, and severe. ${ }^{16}$ Mild and moderate cases have a good prognosis, usually recovering spontaneously or with conservative management. Severe cases need inpatient care. This was a case of severe OHSS. In the management of these patients, close follow up of vitals, body weight, abdominal circumference, and fluid balance is crucial. Blood tests must be checked frequently. ${ }^{17}$ Hyponatremia is a common finding in these patients. Crystalloids are the first choice for fluid replacement. Daily fluid needs change from 1.5 to $3 \mathrm{~L}$. Volume expanders such as dextran, albumin, hydroxyethyl starch (HES), and fresh plasma can also be 
used. ${ }^{1}$ Prophylactic use of heparin is necessary for thromboprophylaxis in patients at risk of thromboembolism. Cabergoline is a dopamine receptor agonist that decreases vascular permeability by inhibiting VEGF receptors. ${ }^{18}$ Steroids are effective since there is an inflammatory response in OHSS. ${ }^{19}$ In our case cabergoline and steroids were used since there was a progression in the disease. After 4 weeks of treatment, clinical and laboratory findings were normalized in our case and the patient was discharged from the hospital. She delivered uneventfully at 37th week of gestation. Cabergoline, when given at the time of diagnosis of OHSS, appears to work rapidly and effectively to diminish the clinical symptoms of the disease.

\section{Conclusion}

Severe OHSS is a life threatening complication of ovarian hyperstimulation. Spontaneous OHSS is a rare entity, which occurs in gestations without ovulation induction. Early diagnosis may prevent unwanted results of the disease.

This study was presented at the Palandöken Gynecology and Obstetrics Winter Congress, 05-08 March 2014 Erzurum/ TURKEY.

\section{References}

1. Schenker JG, Ezra Y. Complications of assisted reproductive techniques. Fertil Steril. 1994 Mar;61(3):411-22. PubMed PMID: 8137959.
2. Forman RG, Frydman R, Egan D, Ross C, Barlow DH. Severe ovarian hyperstimulation syndrome using agonists of gonadotropin-releasing hormone for in vitro fertilization: a European series and a proposal for prevention. Fertil Steril. 1990 Mar;53(3):502-9. PubMed PMID: 2106456.

3. Abu-Louz SK, Ahmed AA, Swan RW. Spontaneous ovarian hyperstimulation syndrome with pregnancy. Am J Obstet Gynecol. $1997 \quad$ Aug;177(2):476-7. http://dx.doi.org/10.1016/S0002-

9378(97)70225-4. PubMed PMID: 9290478.

4. Todros $\mathrm{T}$, Carmazzi CM, Bontempo $\mathrm{S}$, Gaglioti P, Donvito V, Massobrio M. Spontaneous ovarian hyperstimulation syndrome and deep vein thrombosis in pregnancy: case report. Hum Reprod. 1999 Sep;14(9):2245-8. http://dx.doi.org/10.1093/humrep/14.9.2 245. PubMed PMID: 10469688.

5. Speroff I, Glass RH and Kase NG. (eds) Clinical Gynecologic Endocrinology and Infertility, 5th edn. Williams \& Wilkins, Baltimore, MD, 1994; pp 915-917.

6. Fulghesu AM, Villa P, Pavone V, Guido M, Apa R, Caruso A, Lanzone A, Rossodivita A, Mancuso S. The impact of insulin secretion on the ovarian response to exogenous gonadotropins in polycystic ovary syndrome. J Clin Endocrinol Metab. 1997 Feb;82(2):6448.

http://dx.doi.org/10.1210/jcem.82.2.3727 . PubMed PMID: 9024269.

7. Smits G, Olatunbosun $O$, Delbaere $A$, Pierson R, Vassart G, Costagliola S. Ovarian hyperstimulation syndrome due to a mutation in the follicle-stimulating hormone receptor. N Engl J Med. 2003 Aug 21;349(8):760-6. http://dx.doi.org/10.1056/NEJMoa03006 4. PubMed PMID: 12930928. 
8. De Leener A, Montanelli L, Van Durme J, Chae H, Smits G, Vassart G, Costagliola S. Presence and absence of follicle-stimulating hormone receptor mutations provide some insights into spontaneous ovarian hyperstimulation syndrome physiopathology. J Clin Endocrinol Metab. 2006 Feb;91(2):55562. Epub 2005 Nov 8. http://dx.doi.org/10.1210/jc.2005-1580.

PubMed PMID: 16278261.

9. Sahin L, Yavuzcan A. Recurrent spontaneous ovarian hyperstimulation in a virgin girl. Ginekol Pol. 2013 Jul;84(7):647-9. PubMed PMID: 24032279.

10. Griesinger G, Dafopoulos K, SchultzeMosgau A, Jelkmann W, von Otte S, Diesing D, Diedrich K. Vascular endothelial growth factor response to exogenous chorionic gonadotropic hormone in the luteal phase of women with a history of severe ovarian hyperstimulation syndrome. Arch Gynecol Obstet. 2006 Apr;274(1):29-33. Epub $2006 \quad$ Jan 12. http://dx.doi.org/10.1007/s00404-0050112-0. PubMed PMID: 16408189.

11. Rizk B, Aboulghar M, Smitz J, Ron-El R. The role of vascular endothelial growth factor and interleukins in the pathogenesis of severe ovarian hyperstimulation syndrome. Hum Reprod Update. 1997 MayJun;3(3):255-66. doi: 10.1093/humupd/3.3.255. PubMed PMID: 9322101.

12. Phillips HS, Hains J, Leung DW, Ferrara $\mathrm{N}$. Vascular endothelial growth factor is expressed in rat corpus luteum. Endocrinology. 1990 Aug;127(2):965-7. http://dx.doi.org/10.1210/endo-127-2965. PubMed PMID: 2197082.
13. Ravindranath N, Little-Ihrig L, Phillips HS, Ferrara N, Zeleznik AJ. Vascular endothelial growth factor messenger ribonucleic acid expression in the primate ovary. Endocrinology. 1992 Jul;131(1):254-60. PubMed PMID: 1612003.

14. Ferrero H, García-Pascual CM, Gaytán M, Morales C, Simón C, Gaytán F, Pellicer A, Gómez R. Dopamine receptor 2 activation inhibits ovarian vascular endothelial growth factor secretion in an ovarian hyperstimulation syndrome (OHSS) animal model: implications for treatment of OHSS with dopamine receptor 2 agonists. Fertil Steril. 2014 Sep 10. pii: S00150282(14)01881-0. doi: 10.1016/j.fertnstert.2014.07.1240. [Epub ahead of print] PubMed PMID: 25217874.

15. Nouri K, Haslinger $P$, Szabo L, Sator $M$, Schreiber M, Schneeberger C, Pietrowski D. Polymorphisms of VEGF and VEGF receptors are associated with the occurrence of ovarian hyperstimulation syndrome (OHSS)-a retrospective case-control study. J Ovarian Res. 2014 May 13;7:54. doi: 10.1186/1757-2215-7-54. eCollection 2014. PubMed PMID: 24851136.

16. Golan A, Ron-el R, Herman A, Soffer $Y$, Weinraub Z, Caspi E. Ovarian hyperstimulation syndrome: an update review. Obstet Gynecol Surv. 1989 Jun;44(6):430-40. http://dx.doi.org/10.1097/00006254198906000-00004. PubMed PMID: 2660037.

17. Nugent $D$, Vandekerckhove $P$, Hughes E, Arnot M, Lilford R. Gonadotrophin therapy for ovulation induction in subfertility associated with polycystic ovary syndrome. Cochrane Database Syst Rev. 2000;(4):CD000410. PubMed PMID:11034687. 
18. Gomez R, Gonzalez-Izquierdo $M$, Zimmermann RC, Novella-Maestre E, Alonso-Muriel I, Sanchez-Criado J, Remohi J, Simon C, Pellicer A. Lowdose dopamine agonist administration blocks vascular endothelial growth factor (VEGF)-mediated vascular hyperpermeability without altering VEGF receptor 2-dependent luteal angiogenesis in a rat ovarian hyperstimulation model. Endocrinology. 2006 Nov;147(11):5400-11. Epub 2006

Aug

http://dx.doi.org/10.1210/en.2006-0657.

PubMed PMID: 16901966.

19. Vanky E, Kjøtrød SB, Maesel A, Bjerve KS, Carlsen SM. Dexamethasone reduces androgen levels in metformintreated patients with polycystic ovary syndrome. Fertil Steril. 2004 Feb;81(2):459-62.

http://dx.doi.org/10.1016/j.fertnstert.200 3.06.022. PubMed PMID: 14967392. 